\title{
Molecular Bird Sexing on Fischeri Lovebird (Agapornis fischeri) by Using Polymerase Chain Reaction
}

\author{
Azalea Dyah Argarini ${ }^{1}$, Herjuno Ari Nugroho ${ }^{2}$, Medania Purwaningrum ${ }^{1}$ and Aris Haryanto ${ }^{1}$ \\ ${ }^{1}$ Department of Biochemistry and Molecular Biology, Faculty of Veterinary Medicine, Universitas Gadjah Mada, Yogyakarta. \\ J1. Fauna 2 Karangmalang, Yogyakarta 55281, Indonesia. \\ ${ }^{2}$ Research Center for Biology, Indonesian Institute of Sciences (LIPI), Jl Jakarta-Bogor km.46, Cibinong, West Java, Indonesia, \\ 16911
}

\begin{abstract}
Fischeri Lovebird (Agapornis fischeri) found originally in Africa which has spread to many countries. In Indonesia, Fischeri Lovebird is popular as a pet animal. This lovebird is a monomorphic bird, so it is difficult to differentiate morphologically between male and female birds. In general, a male lovebird has ZZ homozygotes, whereas females' lovebird has ZW heterozygous of their sex chromosome. These sex chromosomes set used as study targets for molecular bird sexing of many species of birds because this method is effective and simple to perform. This method targeted to amplify the Chromodomain Helicase DNA-binding (CHD) gene, which found into the sex chromosome of male and female birds. The objective of this study was to rapid molecular bird sexing of Fischeri Lovebird by using PCR methods. Research samples were collected from feather calamus of $A$. fischeri. The total sample was 11 feathers from $A$. fischeri. which were collected three to six feathers for each lovebird. Then the research was followed by DNA extraction from calamus feathers, DNA amplification by PCR and agarose gel electrophoresis of PCR products and visualization of PCR predicts by UVTransilluminator in darkroom. It concluded that PCR amplification using NP, MP and P2 primers produced double DNA bands in size of $400 \mathrm{bp}$ on $\mathrm{Z}$ chromosome and bp on W chromosome for female Fischeri Lovebird, whereas for male Fischeri Lovebird only produced a single DNA band in size of 400 bp on $\mathrm{Z}$ chromosome. From eleven samples of Fischeri Lovebird showed a total of five females and six male Fischeri Lovebirds.
\end{abstract}

\section{Introduction}

Lovebird is a common name for small parrots belongs to genus Agapornis, family Psittaculidae, Order Psittaciformes [1]. The bird is about $15 \mathrm{~cm}$ long, characterized by a short blunt tail, a relatively large, sharp beak, zygodactyl feet, and have a variety of colors on their upper body, depending on the species. Lovebird is a very vocal, playful, and active bird [2]. In Indonesia, lovebirds are very popular as a pet animal, the result that lovebird breeding is a promising business [3].

Lovebird is divided into two groups, namely the dimorphic and monomorphic groups. Dimorphic meaning there are differences between males and females of the same species, including the Agapornis cana, Attaranta, and A.pullaria. Monomorphic meaning there are no differences between males and females of the same species, including A. swinderniana, A. nigrigenis, A. fischeri, A. personata, A. lilianae, and A.roseicollis [2]. The objective of this study was to rapid molecular bird sexing of Fischeri Lovebird by using PCR methods.

\section{Material and Methods}

This research was conducted at the Biochemistry Laboratory, Faculty of Veterinary Medicine, Universitas Gadjah Mada. The research samples were feathers from 11 Fischeri Lovebird (A. fischeri) from bird owners and were labeled with AF1 to AF11. Deoxyribonucleic acid (DNA) was isolated from samples based on the Gsync DNA Extraction Kit (Geneaid, Taiwan) protocol, but the incubation time was extended to overnight aimed at making DNA well extracted so that the DNA bands produced when exposed to UV light became clear.

The results of DNA isolation were used as DNA templates in the process of amplification using the PCR method. DNA fragments were amplified by targeting the CHD gene on the sex chromosome using P2, NP, and MP primers. Primary base arrangements and PCR products are presented in Table 1. A mixture of $25 \mu \mathrm{L}$ of PCR reagents for bird DNA in one reaction consists of $12,5 \mu \mathrm{l}$ MyTaq $^{\mathrm{TM}}$ DNA Polymerase, $1 \mu \mathrm{l}$ forward primer [10 pmol], $1 \mu \mathrm{l}$ reverse primer [10 pmol], and $9,5 \mu \mathrm{l}$ isolated DNA. The mixture was put into the PCR machine with controlled temperature and duration of the PCR reaction, beginning with predenaturation of $94^{\circ} \mathrm{C}$ for 2 minutes, denaturation of $94^{\circ} \mathrm{C}$ for 20 seconds, annealing $46^{\circ} \mathrm{C}$ for 30 seconds, the extension of $72^{\circ} \mathrm{C}$ for 40 seconds, and a final extension at $72^{\circ} \mathrm{C}$ for 10 minutes. The denaturation, annealing, and extension stages were repeated as many as 40 cycles.

The results of DNA and PCR isolation can be identified by DNA electrophoresis. Ten DNA samples mixed with loading dye were compared with $100 \mathrm{bp}$ hyperladder markers (Bioline, UK) Electrophoresis was done with a $2.5 \%$ agarose gel at a voltage of 100 volts and an electric current of 75 amperes for 45 minutes. DNA bands were observed using UV-Transilluminator wavelength of $280 \mathrm{~nm}$.

\footnotetext{
Corresponding author: arisharyanto@ugm.ac.id
} 
Table 1. Nucleotide sequence of primers used in this research and the primer references.

\begin{tabular}{ccc}
\hline $\begin{array}{c}\text { Primer } \\
\text { Code }\end{array}$ & \multicolumn{1}{c}{ Nucleotide Sequences } & Primer \\
\hline NP-F $^{*}$ & 5'-GAGAAACTGTGCAAAACAG-3' & Forward \\
P2-R $^{*}$ & 5'-TCTGCATCGCTAAATCCTTT-3' & Reverse \\
MP-R $^{* *}$ & 5'-AGTCACTATCAGATCCGGAA-3' & Reverse \\
\hline$*[7] ; *[8]$ & &
\end{tabular}

\section{Results}

Blood and feather can be used as a sample for molecular sexing [9], blood samples contain more DNA than the feathers but need more energy to handle the bird. Improper handling can cause birds stress, even death. Feather as a sample has advantages, such as easier and faster to collect, less stressful on the birds, the storage requirements for samples are simpler and less expensive compared to the blood samples. The quantity of DNA that can be isolated from feathers was not as much as DNA that was isolated from blood, but with consideration of speed, convenience, and minimal risk, feathers were chosen as samples to molecular birds sexing [9].

Researchers stated that the source of DNA in feathers was obtained from the base of the feather calamus which contains many epithelial cells and contained inhibitors, namely keratin, making the extraction process quite difficult [10]. The results of DNA extraction using a kit produce better DNA quality, but by using of kits will increase costs. The kit used for DNA extraction in this study was Gsync DNA Extraction Kit (Geneaid, Taiwan) but the incubation time was extended to overnight so that DNA can be extracted properly. Electrophoresis of DNA isolation products (Figure 1) were visualized under 280 nm UV light with a $100 \mathrm{bp}$ DNA ladder marker produced a luminous DNA fragment due to the presence of SYBRsafe in the samples. DNA bands were seen in samples nine, ten, and eleven. Samples that were empty and did not display DNA bands showed that the DNA in the sample did not exist or very limited quantity, so they cannot be visualized.

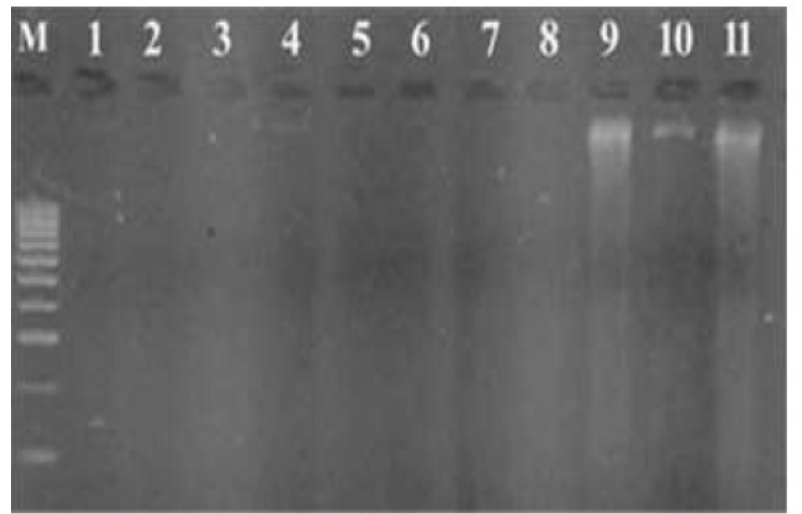

Figure 1. Electrophoresis results from total DNA isolation. $\mathrm{M}=\mathrm{DNA}$ marker (100 bp), 1-11= samples of lovebird
Amplification of the CHD gene with primers set of $\mathrm{NP}, \mathrm{P} 2$, and MP visualized under UV light with a wavelength of $280 \mathrm{~nm}$ produced a DNA band for males and two DNA bands for female Fischeri Lovebirds. It caused that birds have sex chromosome composition which different from mammal's sex chromosomes. Heterogametic properties in birds are owned by female birds (ZW) while male birds are homogeneous (ZZ) [11]. The CHD gene could show differences in $\mathrm{Z}$ and $\mathrm{W}$ alleles in females due to the linkage between the position of the CHD gene and the sex chromosome. The visualization results under UV Transluminator compared to $100 \mathrm{bp}$ hyperladder resulted in a $400 \mathrm{bp}$ PCR product on the Z chromosome and $350 \mathrm{bp}$ on the $\mathrm{W}$ chromosome (Figure 2 and Table 2).

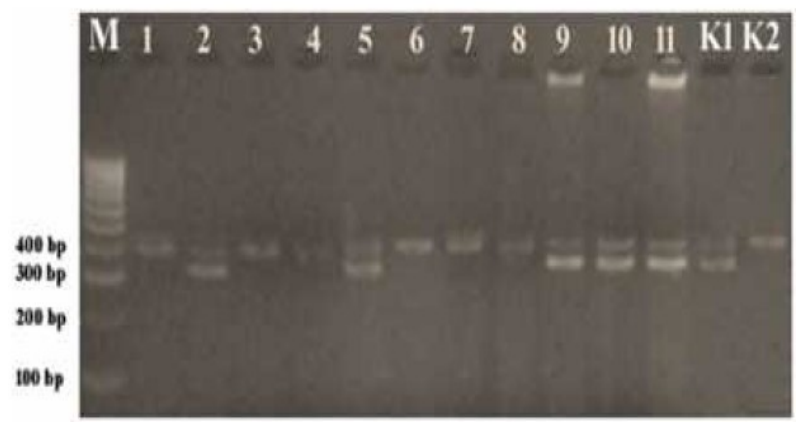

Figure 2. Electrophoresis results of CHD gene amplification samples of lovebird. M= DNA marker (100 bp), 1-11= lovebird samples, $\mathrm{K} 1=$ female control, $\mathrm{K} 2=$ male control.

Table 2. Interpretation of PCR products.

\begin{tabular}{cccc}
\hline No. & $\begin{array}{c}\text { Sample } \\
\text { Code }\end{array}$ & $\begin{array}{c}\text { Electrophoresis } \\
\text { result }\end{array}$ & $\begin{array}{c}\text { Sex } \\
\text { Interpretation }\end{array}$ \\
\hline 1. & AF1 & One band & Male \\
2. & AF2 & Two bands & Female \\
3. & AF3 & One band & Male \\
4. & AF4 & One band & Male \\
5. & AF5 & Two bands & Female \\
6. & AF6 & One band & Male \\
7. & AF7 & One band & Male \\
8. & AF8 & One band & Male \\
9. & AF9 & Two bands & Female \\
10. & AF10 & Two bands & Female \\
11. & AF11 & Two bands & Female \\
\hline
\end{tabular}

Figure 2 showed the electrophoresis results from the PCR products. Lane $1,3,4,6,7$, and 8 there was a single DNA band that indicates that those samples were male Fischeri Lovebird, whereas lanes 2, 5, 9, 10, and 11 showed double DNA bands which means those samples were female Fischeri Lovebirds. This molecular bird sexing on Fischeri Lovebird (Agapornis fischeri) were consistent with the results of molecular bird sexing on other Lovebird species, namely Peach-faced Lovebird (Agapornis roseicollis) reported by researchers who used the same PCR primers set [12]. 
Table 2 showed the confirmation result of PCR products Lovebird no. 1 to 11 . It showed that 6 samples were male Fischeri Lovebirds (AF1, AF3, AF4, AF6, AF7, AF8), while 5 other samples were female Fischeri Lovebirds (AF2, AF5, AF9, AF19. AF11). This result was in line with other researchers, who carried out the molecular bird sexing on some species of captive birds belong to the families of Psittacidae, Cacatuidae, Psittaculidae, Psittrichasiidae, Pelecanidae, Anatidae, Phoenicopteridae, Spheniscidae, Threskiornithidae and Musophagidae [13].

P2 and NP primers were originally designed by Griffith, et al [7], and primer MP was first developed by Ito, et al., [9] to amplify a segment in W sex chromosome only. The P2 and NP were successfully used to differentiate the sex of most bird species, excluding Order Sthrutionioformes [7,14]. The result of the amplification using NP and P2 primers sets in the Fischeri Lovebird samples showed similar size with the other birds from previous publications [7,14,15]. Amplification using NP and MP primers set also showed a similar result with the previous publication [8]. These primers can successfully amplify the segments in $\mathrm{W}$ and $\mathrm{Z}$ in lovebird's sex chromosome, hence it can be used to differentiate the sex of the bird.

\section{Conclusion}

It concluded that PCR amplification using NP, MP, and P2 primers produced double DNA bands in the size of $400 \mathrm{bp}$ on $\mathrm{Z}$ chromosome and bp on $\mathrm{W}$ chromosome for female Fisher Lovebird, whereas for male Fisher Lovebird only produces a single DNA band in size of 400 $\mathrm{bp}$ on the $\mathrm{Z}$ chromosome. Electrophoresis results of eleven Fisher Lovebird samples showed a total of five females and six male lovebirds. The NP, MP, and P2 primers were successfully used to differentiate the sex of lovebirds.

\section{References}

1. P. Myers, R. Espinosa, C. S. Parr, T. Jones, G. S. Hammond, and T. A. Dewey. The Animal Diversity Web (online). Accessed at https://animaldiversity. org., (2020)

2. N. Moustaki. Lovebirds: A Guide to Caring for Your Lovebird. California: Bow Tie Press, (2006)

3. S. Benjamin and . Yasyifa. Teknik rahasia menciptakan variasi warna lovebird: Dijamin pasti berhasil anti gagal. Jakarta: Lembar Langit Indonesia, (2017)

4. B. Handono, R. Turut, and S. Gunarso. Lovebird: Sukses menangkarkan dan memelihara. Jakarta: Penebar Swadaya, (2013)

5. A. Dubiec and M.Z. Neubauer. Molecular technique for sex Identification in birds. Biological Letters 43(1): 3-12, (2006)

6. I. Khaerunisa, E. Sari, and M. Ulfah, Jakaria, C. Sumantri. Avian sex determination based on Chromo
Helicase DNA-binding (CHD) genes using Polymerase Chain Reaction (PCR). Media Peternakan, 36 (2): 85-90, (2013)

7. R. Grifftihs, M.C. Double, K. Orr, and J.G. Dawson. A DNA test to sex most birds. Molecular Ecology, 7: 1071-1075, (1998)

8. H. Ito, A. Sudo-Yamaji, M. Abe, T. Murase, and T. Tsubota. Sex identification by alternative polymerase chain reaction methods in Falconiformes. Zoology Science, 20: 339-344, (2003)

9. M. Harvey, D. Bonter, L. Stenzler, and I. Lovette. Comparison of plucked feathers versus blood samples as DNA sources for molecular sexing. Journal of Field Orthinology, 77(2), 136-140, (2006)

10. C. Hickman, L. Roberts, and F. Hickman. Integrated principles of zoology. Seventh ed. Toronto: Mosby Collage Publishing. 235, (1984)

11.A.K. Fridolfsson. and H.A. Ellegren. A simple and universal method for molecular sexing of non-ratite birds. Jounal of Avian Biology, 30, 116-121, (1999)

12.P. Nugraheni, M. Purwaningrum, R. Widayanti, and A. Haryanto. Sex determination of peach-faced lovebird (Agapornis roseicollis) using polymerase chain reaction (PCR) techniques. IOP Conf. Series: Earth Environ. Sci. 355. 012111, (2019)

13. M. Purwaningrum, H.A. Nugroho, M. Asvan, K. Karyanti, B. Alviyanto, R. Kusuma, and A. Haryanto. Molecular techniques for sex identification of captive birds. Veterinary World, 12 (9): 1506-1513, (2019)

14. S. Sulandari and M.S.A. Zein. Application of two molecular sexing methods for Indonesian bird species: Implication for captive breeding programs in Indonesia. Hayati Journal of Biosciences, 19(4): 183190, (2012)

15.H.A. Nugroho and M.S.A Zein. Evaluasi metode penentuan jenis Kelamin pada Nuri Kepala Hitam (Lorius lory, Linnaeus 1758). Zoo Indonesia, 24(2): 83-93, (2015) 